\title{
ORAL HEALTH BEHAVIOR CHANGE FRAMEWORK IN PRESCHOOLERS: SYSTEMATIC REVIEW
}

\author{
Pahrur Razi*, Muhammad Rusdi, Asni Johari, Syahrial \\ PMIPA Doctoral Program, Concentration of Public Health Education, \\ Jambi University, Jambi, Indonesian
}

\begin{abstract}
BACKGROUND: Pre-school children have difficulty maintaining oral health. Studies show that preschoolers' dental and oral health depends on the attitudes and behavior of their parents towards dental and oral health. This systematic review aims to identify and analyze the framework through the Health Belief Model (HBM) approach and the Theory of Planned Behavior (TPB) for behavioral changes to maintain oral health in pre-school children.

METHOD: This systematic review was conducted using the Preferred Reporting Items for Systematic Reviews and Meta-analyses (PRISMA) statement. The literature search was carried out on the ScienceDirect, Google Scholar, Proquest, Pubmed, and Wiley Online Library databases, with a publication period between 2010 and 2021.

RESULTS: All studies $(\mathrm{n}=10)$ were conducted on preschooler oral-health and focused on parents' involvement. Five studies used theory of planned behavior framework, and five studies remaining used the health belief model. All studies confirmed a prominent means in preschoolers oral-health rely on the knowledge, attitude, practice, and beliefs of parents.

CONCLUSIONS: Both the Health Belief Model and the Theory of Planned Behavior can help improve behavior change in pre-school children in maintaining oral health.
\end{abstract}

KEYWORDS: Health Belief Model, Theory of Planned Behavior, Oral Health, Pre-school

\section{Introduction}

The resolution of the World Health Assembly in 2000 was in sync with World Health Organization (WHO's) priorities on the Global Oral Health Programme, consisting of techniques, approaches for preventing dental disease, and promoting health $[1,2]$. It is an urgent need for public health against the threat of non-communicable diseases and the formulation of strategies for disease prevention and control using a practical approach $[3,4]$. Empowering behavior change is better than simply informing individuals, communities, and populations. Individuals are obliged to take greater responsibility for health care and maintenance and adopt healthy behaviors [4].

Regarding the factors of healthy behavior, people are still not aware that oral and dental health behavior is only $2.8 \%$ in the five-year age group [5]. Oral and dental health behavior dramatically influences the occurrence of dental disease, where children aged five years have the highest incidence of dental disease, 93\% [6]. Therefore, improving oral and dental health behavior is highly recommended to prevent dental and oral diseases in children [7].

Oral health is defined as "free from chronic oral and facial pain, oral and throat cancer, thrush, congenital disabilities such as cleft lip and palate, periodontal (gum) disease, tooth decay, and tooth loss, and other diseases and disorders [8]. It affects the oral cavity. The impact of oral health on general health and quality of life is significant because some common infections are caused by the direct effect of untreated oral health problems [9].

* Author correspondent: Pahrur Razi, Jambi St- Muara Bulian No.KM. 15, Mendalo Darat, Kec. Jambi Luar Kota, Kabupaten Muaro Jambi, Jambi, Email: razipahrur64@gmail.com

Article received: 18.11 .2021 , accepted: 7.12 .2021 , published: 15.12 .2021

Cite: Razi P, Rusdi M, Johari A, Syahrial. Oral health behavior change framework in preschoolers: systematic review. The Journal of School and University Medicine. 2021;VIII(4):40-49 
Poor oral health has a substantial impact on many aspects of general health. It is associated with social and environmental behavioral factors that can contribute to poor nutrition, missed work and school hours, pain and suffering, and increased health care costs [10].

Poor oral health can lead to infectious diseases and other degenerative diseases. Therefore, an effective method is needed to improve dental and oral health [11]. In high-income countries, oral health disease is a significant public health problem and is a growing concern in low- and middle-income countries (LMIC) [12]. Therefore, the World Health Organization (WHO) has adopted a strategy of prevention and promotion of oral health needs and has been working to increase awareness of oral health worldwide as an essential component of public health and quality of life in the Global Oral Health Programme [13]. Dental health education can be delivered to a broad group of people through dentistry in schools, workplaces, daycare centers, and nursing homes [14]. Health education for parents is essential because of their role in the care of their children [15].

Preschool children have difficulty in maintaining oral health. Various interventions have been designed and evaluated. However, the effectiveness of the intervention depends on the continuity and intensity of the meeting or session [16]. To support oral health promotion methods, experts seek to explore the use of various health education media and health promotion intervention models for preschool children [17]. Therefore, the acceleration of the learning process is influenced by game-based interventions by increasing the willingness to maintain the required oral health. These findings have led to the development of oral health promotion models for preschool children and intervention tools [18].

Studies show that preschoolers' dental and oral health depends on the attitudes and behavior of their parents towards dental and oral health. In particular, children are more likely to have better dental health behaviors and outcomes if their mothers have positive attitudes toward oral health [19-21].

This systematic review aims to identify and analyze the framework through the Health Belief Model (HBM) approach and the Theory of Planned Behavior (TPB) for behavioral changes to maintain oral health in pre-school children. This study examines articles that have been published in the period 2015 to 2021 .

\section{Methods}

\section{Review Protocol}

This systematic review was conducted using the Preferred Reporting Items for Systematic Reviews and Meta-analyses (PRISMA) statement. Through this study, the authors try to develop a framework for behavioral change in oral health in pre-school children based on the results of previously published studies.

\section{Searching strategies}

Relevant articles were searched and collected using Sciencedirect, Google Scholar, Proquest, Pubmed, and Wiley Online Library, with a publication period between 2015 to 2021. The author adjusted the search keywords according to the Mesh terms for health studies. The keywords used vary, depending on the search engine used. In general, keywords focus on the 'Health Belief Model' OR 'Theory of Planned Behavior' OR 'Intervention Model' OR 'Parental' OR 'Behavior' OR 'Behavioral change' OR 'Behavioral improvement' OR empower* AND 'Oral Health' OR 'Oral Hygiene' AND 'Child' OR 'Children' OR 'Preschooler.'

\section{Inclusion and Exclusion Criteria}

Inclusion criteria consist of intervention studies, programs, training, or educational strategies to support changes in children's behavior in maintaining oral health. It also includes analyzing the effectiveness of the intervention by measuring changes in children's knowledge, attitudes, perceptions, or practices in maintaining oral health, focusing on the parent, the child, or both. The search strategy focuses on databases and publications in English and Indonesian. Articles were excluded or not reviewed if they only discussed the prevalence of oral health disorders and did not refer to intervention strategies or health promotion.

\section{Data extraction and analysis}

Titles and abstracts are screened on each database. Screening for duplicate articles is carried out using the Mendeley application. Substantive information is extracted from each study into a Microsoft Word table. 
The author determined the selection of papers after being reviewed from 10 full-text articles that adjusted to the inclusion and exclusion criteria. Data extraction was carried out with care. The interpretations are presented in the table by taking the critical parts of the article.

\section{Study quality}

Overall articles were assessed using the National Institutes of Health (NIH) study quality assessment tool for observational cohort and cross-sectional studies and intervention studies using the National Institutes of Health (NIH) quality assessment of controlled intervention studies. A developed scoring sheet conducts to assess the research methodology and adherence to the scoring criteria for each article that met the inclusion criteria of this study. Articles with scores $<30 \%$ of the standards were classified as "poor" scores between 30 and $70 \%$ were classified as "moderate" and scores $>70 \%$ were classified as "good" study quality. The articles taken are classified as "moderate" and "good."

\section{Results}

The search returned 11,504 articles. after removing the duplicated articles, 3,041 articles remained, removing 8,463 pieces after screening titles and abstracts. The remaining 26 papers were reviewed and checked for eligibility, so 16 articles were excluded. The final results were as many as ten articles that met the inclusion criteria.

Table 1. Characteristics of studies that match the inclusion criteria

\begin{tabular}{|c|c|c|c|c|c|c|}
\hline Author, Title, Year & Country & Sample & Outcome & Framework & $\begin{array}{l}\text { Evaluation } \\
\text { Methods }\end{array}$ & Result \\
\hline $\begin{array}{l}\text { Soltani et al, } 2018 . \\
\text { Determinants of } \\
\text { Oral Health Behav- } \\
\text { ior among Preschool } \\
\text { Children: Applica- } \\
\text { tion of the Theory } \\
\text { of Planned Behavior } \\
\text { [22] }\end{array}$ & Iran & $\begin{array}{l}833 \text { moth- } \\
\text { er-child } \\
\text { pairs }\end{array}$ & $\begin{array}{l}\text { Oral Health Be- } \\
\text { havior }\end{array}$ & $\begin{array}{l}\text { Theory of } \\
\text { Planned Be- } \\
\text { havior }\end{array}$ & $\begin{array}{l}\text { Questionnaire: the } \\
\text { child's tooth brush- } \\
\text { ing frequency, the } \\
\text { frequency of child's } \\
\text { tooth brushing as- } \\
\text { sisted by parent. }\end{array}$ & $\begin{array}{l}\text { There is } \\
\text { positive rela- } \\
\text { tionship be- } \\
\text { tween all TPB } \\
\text { structures and } \\
\text { children's oral } \\
\text { health behav- } \\
\text { ior. }\end{array}$ \\
\hline $\begin{array}{l}\text { Adiatman et al., } \\
2017 \text {. The Cor- } \\
\text { relation between } \\
\text { Mothers' Behaviors } \\
\text { of Maintaining } \\
\text { Their Children's } \\
\text { Oral Hygiene and } \\
\text { Early Childhood } \\
\text { Caries (Based on the } \\
\text { Theory of Planned } \\
\text { Behavior) [23] }\end{array}$ & Indonesia & $\begin{array}{l}295 \text { pairs } \\
\text { of mothers } \\
\text { and chil- } \\
\text { dren }\end{array}$ & $\begin{array}{l}\text { the relation be- } \\
\text { tween mothers' } \\
\text { dental and oral } \\
\text { health behaviors } \\
\text { and Early Child- } \\
\text { hood Caries } \\
\text { (ECC) in chil- } \\
\text { dren. }\end{array}$ & $\begin{array}{l}\text { Theory of } \\
\text { Planned Be- } \\
\text { havior }\end{array}$ & $\begin{array}{l}\text { Questionnaire Inter- } \\
\text { view, and intra-oral } \\
\text { examination of the } \\
\text { children }\end{array}$ & $\begin{array}{l}\text { There was no } \\
\text { correlation } \\
\text { between moth- } \\
\text { ers' behaviors } \\
\text { of maintaining } \\
\text { their children's } \\
\text { oral hygiene } \\
\text { and ECC. }\end{array}$ \\
\hline $\begin{array}{l}\text { Clarke \& Ridley, } \\
\text { 2018. Parental At- } \\
\text { titudes and Beliefs } \\
\text { About Preschooler } \\
\text { Preventive Oral } \\
\text { Health Behav- } \\
\text { iors: Implications } \\
\text { for Health Promo- } \\
\text { tion [24] }\end{array}$ & $\begin{array}{l}\text { United } \\
\text { States }\end{array}$ & $\begin{array}{l}192 \text { par- } \\
\text { ents/ } \\
\text { guardians } \\
\text { of Black, } \\
\text { preschool } \\
\text { children } \\
\text { (ages 3-5) }\end{array}$ & $\begin{array}{l}\text { Parental atti- } \\
\text { tudes, beliefs, } \\
\text { and behaviors } \\
\text { about caries pre- } \\
\text { ventive behav- } \\
\text { iors among their } \\
\text { Black preschool } \\
\text { children. }\end{array}$ & $\begin{array}{l}\text { Theory of } \\
\text { Planned Be- } \\
\text { havior }\end{array}$ & $\begin{array}{l}\text { The oral health ques- } \\
\text { tionnaire contained } \\
114 \text { questions, and } \\
\text { included The Interna- } \\
\text { tional Collaborative } \\
\text { Study on Child Dental } \\
\text { Health Questionnaire } \\
\text { to Parents (CDHQ) } \\
\text { containing } 100 \text { ques- } \\
\text { tions [19], and The } \\
\text { Child Nutrition Ques- } \\
\text { tionnaire (CNQ) con- } \\
\text { taining } 14 \text { questions. }\end{array}$ & $\begin{array}{l}\text { Parental at- } \\
\text { titudes and } \\
\text { beliefs, in- } \\
\text { cluding inten- } \\
\text { tions, about } \\
\text { children's oral } \\
\text { health were as- } \\
\text { sociated with } \\
\text { oral health } \\
\text { behaviors. }\end{array}$ \\
\hline
\end{tabular}




\begin{tabular}{|c|c|c|c|c|c|c|}
\hline Author, Title, Year & Country & Sample & Outcome & Framework & $\begin{array}{c}\text { Evaluation } \\
\text { Methods }\end{array}$ & Result \\
\hline $\begin{array}{l}\text { Gharlipour et al., } \\
\text { 2016. Factors Af- } \\
\text { fecting Oral-Dental } \\
\text { Health in Children } \\
\text { in the Viewpoints of } \\
\text { Mothers Referred to } \\
\text { the Health Centers } \\
\text { in Qom City: Using } \\
\text { the Health Belief } \\
\text { Model [25] }\end{array}$ & Iran & $\begin{array}{l}300 \text { moth- } \\
\text { ers who } \\
\text { had health } \\
\text { records for } \\
\text { their chil- } \\
\text { dren and } \\
\text { referred to } \\
\text { the Qom } \\
\text { health cen- } \\
\text { ters }\end{array}$ & $\begin{array}{l}\text { Mothers' be- } \\
\text { havior, child } \\
\text { behavior }\end{array}$ & $\begin{array}{l}\text { Health Belief } \\
\text { Model }\end{array}$ & $\begin{array}{l}\text { Questionnaire related } \\
\text { to the Health Belief } \\
\text { Model }\end{array}$ & $\begin{array}{l}\text { There was a } \\
\text { positive and } \\
\text { significant } \\
\text { relationship } \\
\text { between the } \\
\text { mothers' be- } \\
\text { havior towards } \\
\text { oral-dental } \\
\text { health with } \\
\text { perceived } \\
\text { benefits and } \\
\text { self-efficacy. }\end{array}$ \\
\hline $\begin{array}{l}\text { Hiratsuka et al., } \\
\text { 2019. Oral health } \\
\text { beliefs and oral } \\
\text { hygiene behaviours } \\
\text { among parents of } \\
\text { urban Alaska Native } \\
\text { children [26] }\end{array}$ & USA & $\begin{array}{l}100 \text { Par- } \\
\text { ents/care- } \\
\text { giver of } \\
\text { children } 71 \\
\text { months }\end{array}$ & $\begin{array}{l}\text { Tooth-brushing } \\
\text { frequency }\end{array}$ & $\begin{array}{l}\text { Health Belief } \\
\text { Model }\end{array}$ & $\begin{array}{l}\text { The Oral Health Be- } \\
\text { lief Questionnaire } \\
\text { contains } 18 \text { items, } 9 \\
\text { of which were used in } \\
\text { the composite survey, } \\
\text { which measure di- } \\
\text { mensions of the health } \\
\text { belief model grouped } \\
\text { into } 5 \text { oral health be- } \\
\text { lief scales }\end{array}$ & $\begin{array}{l}\text { Parental tooth- } \\
\text { brush-ing } \\
\text { had a strong } \\
\text { positive asso- } \\
\text { ciation with } \\
\text { the belief that } \\
\text { oral health is } \\
\text { as important } \\
\text { as physical } \\
\text { health. }\end{array}$ \\
\hline $\begin{array}{l}\text { Hossein, B.M.M, et } \\
\text { al., } 2015 \text {. Evaluation } \\
\text { of oral hygiene care } \\
\text { of under } 4 \text { years old } \\
\text { children by their } \\
\text { mothers based on } \\
\text { the Health Belief } \\
\text { Model [27] }\end{array}$ & Iran & $\begin{array}{l}200 \text { moth- } \\
\text { ers with } \\
\text { children } \\
\text { under } \\
\text { 4years }\end{array}$ & $\begin{array}{l}\text { Oral health care } \\
\text { status of children } \\
\text { under } 4 \text { by their } \\
\text { mother }\end{array}$ & $\begin{array}{l}\text { Health Belief } \\
\text { model }\end{array}$ & \begin{tabular}{|l|} 
Questionnaire with \\
42 questions about 8 \\
constructs of HBM \\
(knowledge, per- \\
ceived susceptibility, \\
perceived severity, \\
perceived benefits, \\
perceived barrier, \\
self - efficacy, cues to \\
action and preventive \\
behavior)
\end{tabular} & $\begin{array}{l}\text { There is signif- } \\
\text { icant relation- } \\
\text { ship with the } \\
\text { oral and dental } \\
\text { health behav- } \\
\text { iors of children } \\
\text { by their moth- } \\
\text { ers. }\end{array}$ \\
\hline $\begin{array}{l}\text { Wilson et al., } 2018 . \\
\text { Validity of Measures } \\
\text { Assessing Oral } \\
\text { Health Beliefs of } \\
\text { American Indian } \\
\text { Parents [28] }\end{array}$ & USA & $\begin{array}{l}1016 \text { par- } \\
\text { ent-child } \\
\text { dyads }\end{array}$ & $\begin{array}{l}\text { Measurement } \\
\text { of EHBM con- } \\
\text { structs in relation } \\
\text { to the influence } \\
\text { of parents' be- } \\
\text { liefs on the oral } \\
\text { health outcomes } \\
\text { of their children. }\end{array}$ & $\begin{array}{l}\text { Health Belief } \\
\text { Model }\end{array}$ & $\begin{array}{l}\text { Basic Research Fac- } \\
\text { tors Questionnaire } \\
\text { (BRFQ) }\end{array}$ & $\begin{array}{l}\text { Questionnaire } \\
\text { items assess- } \\
\text { ing the EHBM } \\
\text { theoretical } \\
\text { constructs are } \\
\text { reliable and } \\
\text { valid as mea- } \\
\text { sures of key } \\
\text { parental be- } \\
\text { liefs influenc- } \\
\text { ing children's } \\
\text { oral-health } \\
\text { outcomes in an } \\
\text { AI population }\end{array}$ \\
\hline
\end{tabular}




\begin{tabular}{|c|c|c|c|c|c|c|}
\hline Author, Title, Year & Country & Sample & Outcome & Framework & $\begin{array}{c}\text { Evaluation } \\
\text { Methods } \\
\end{array}$ & Result \\
\hline $\begin{array}{l}\text { Wilson et al., } 2016 . \\
\text { Validation and Im- } \\
\text { pact of Caregivers' } \\
\text { Oral Health Knowl- } \\
\text { edge and Behavior } \\
\text { on Children's Oral } \\
\text { Health Status [29] }\end{array}$ & USA & $\begin{array}{l}992 \text { Ameri- } \\
\text { can Indian/ } \\
\text { Alaska } \\
\text { Native } \\
\text { caregivers } \\
\text { with a child } \\
\text { aged three } \\
\text { to five } \\
\text { years }\end{array}$ & $\begin{array}{l}\text { oral health } \\
\text { knowledge and } \\
\text { behavior }\end{array}$ & $\begin{array}{l}\text { Health Belief } \\
\text { Model }\end{array}$ & $\begin{array}{l}\text { The Basic Research } \\
\text { Factors Questionnaire } \\
\text { (BRFQ) }\end{array}$ & $\begin{array}{l}\text { Caregiver oral } \\
\text { health knowl- } \\
\text { edge was sig- } \\
\text { nificantly as- } \\
\text { sociated with } \\
\text { education, } \\
\text { income, oral } \\
\text { health behav- } \\
\text { ior, and all but } \\
\text { one of the oral } \\
\text { health attitude } \\
\text { measures. }\end{array}$ \\
\hline $\begin{array}{l}\text { Elyasi et al., } 2020 . \\
\text { Modeling the The- } \\
\text { ory of Planned Be- } \\
\text { haviour to predict } \\
\text { adherence to preven- } \\
\text { tive dental visits in } \\
\text { preschool children } \\
\text { [30] }\end{array}$ & Canada & $\begin{array}{l}370 \text { partici- } \\
\text { pants }\end{array}$ & $\begin{array}{l}\text { dental atten- } \\
\text { dance behavior } \\
\text { in preschoolers }\end{array}$ & $\begin{array}{l}\text { Theory of } \\
\text { Planned Be- } \\
\text { havior }\end{array}$ & $\begin{array}{l}\text { 24-item validated } \\
\text { questionnaire based } \\
\text { on Azjen's Theory of } \\
\text { Planned Behaviour } \\
\text { (TPB) constructs } \\
\text { adopted to examine } \\
\text { parental attitudes ( } 8 \\
\text { items), subjective } \\
\text { norms ( } 10 \text { items), } \\
\text { PBC (5 items), and } \\
\text { intention ( } 1 \text { item) to- } \\
\text { wards their preschool- } \\
\text { ers' dental attendance }\end{array}$ & $\begin{array}{l}\text { Parent's SOC } \\
\text { significantly } \\
\text { predicted TPB } \\
\text { components } \\
\text { and dental at- } \\
\text { tendance. }\end{array}$ \\
\hline $\begin{array}{l}\text { Makvandi et al., } \\
\text { 2015. Evaluation } \\
\text { of an Oral Health } \\
\text { Intervention among } \\
\text { Mothers of Young } \\
\text { Children: A Clus- } \\
\text { tered Randomized } \\
\text { Trial [31] }\end{array}$ & Iran & $\begin{array}{l}90 \text { mothers } \\
\text { of } 1-2 \text { year } \\
\text { old children }\end{array}$ & $\begin{array}{l}\text { Mothers be- } \\
\text { havior of teeth } \\
\text { cleaning of chil- } \\
\text { dren aged } 1-2 \\
\text { years }\end{array}$ & $\begin{array}{l}\text { Theory of } \\
\text { Planned Be- } \\
\text { havior }\end{array}$ & $\begin{array}{l}\text { Questionnaire and } \\
\text { interview }\end{array}$ & $\begin{array}{l}\text { TPB interven- } \\
\text { tion among } \\
\text { mothers of } \\
1-2 \text { years old } \\
\text { children may } \\
\text { be effective in } \\
\text { improve the } \\
\text { cleaning of } \\
\text { children's teeth } \\
\text { and related } \\
\text { cognitions. }\end{array}$ \\
\hline
\end{tabular}

\section{Study Characteristics}

Most of the literature included is quantitative with a cross-sectional approach [22-27,30], and randomized trial [29,31], with quality assessment scores for ten studies that met the criteria. Inclusion ranges from moderate to good. A total of 4,388 participants were sampled across the studies included in this review. Included articles were published from 2015 to 2020 and were conducted in 4 countries located in the USA $(n=4)$, Iran $(n=4)$, Canada $(n=1)$, and Indonesia $(n=1)$. Oral health behavior was the most common outcome in the included studies found in five studies $[22,23,25,28,29]$. Parental attitudes, beliefs, and behaviors [24], toothbrushing frequency
[26], dental attendance [30], parents belief [28], and mother behavior [31] as other outcomes. In general, based on the framework of the studies included in this study, it consists of two theories, namely the Health Belief Model used in 5 studies [25-29], and five studies using the Theory of Planned Behavior model [22-24,30,31].

\section{Health Belief Model Framework for Changes in Children's Oral Health}

The use of the Health Belief Model (HBM) framework in the application of the study is mainly related to the respondent's behavioral assessment instrument based on question items related to the dimensions of the HBM model. 


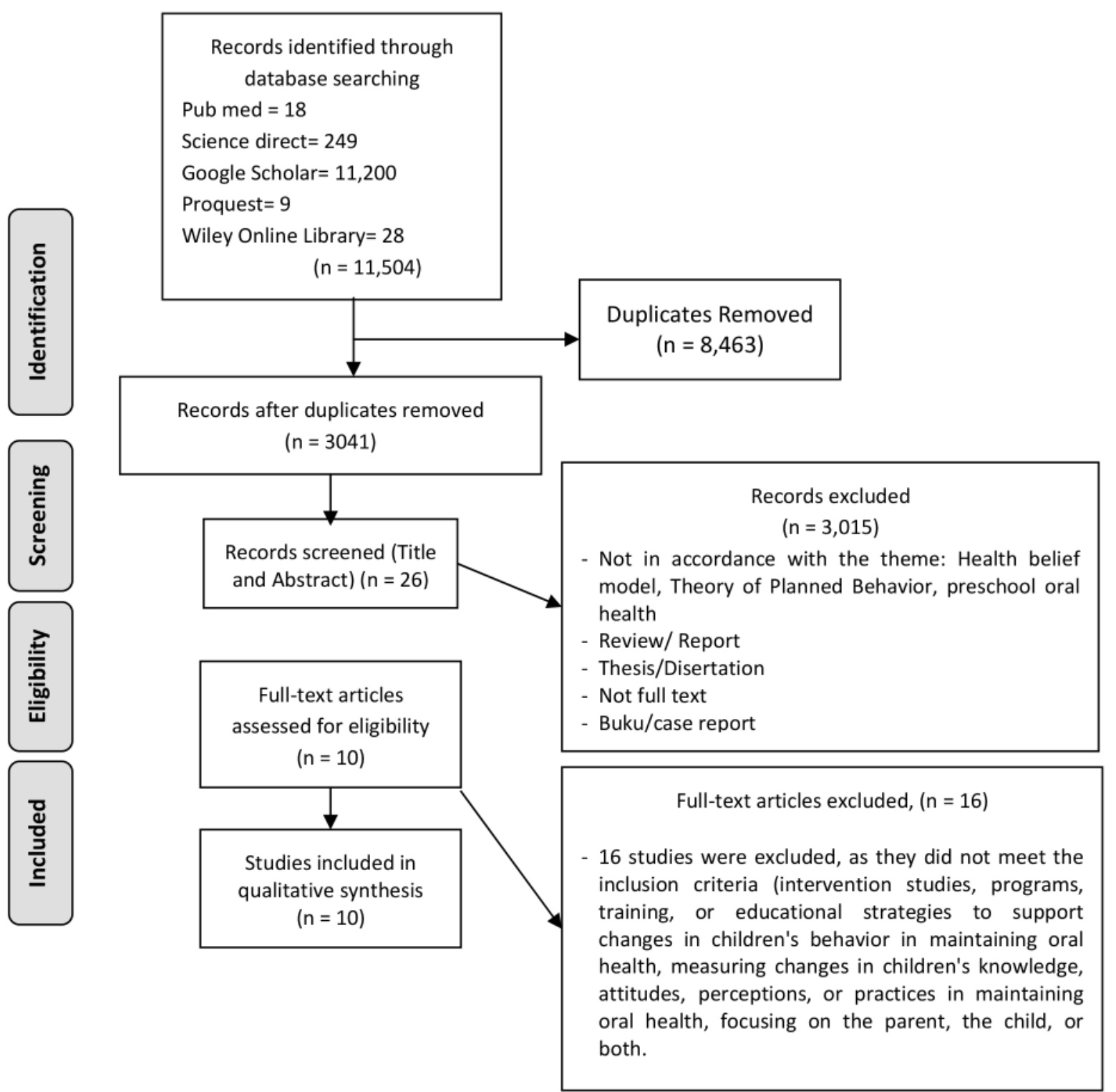

Gharlipour and his team conducted several questions arranged based on dimensions in the Health Belief Model (HBM), ranging from awareness of the health status of children's teeth and mouth with the example of the question "What are the signs of dental caries?", perceptions of vulnerability to the possibility of suffering from dental and oral diseases sample question "In my opinion, tooth decay happens more in old age and my child will not suffer tooth decay." of my child.", the perceived benefits for dental and oral health by brushing and flossing with the example of the question "I think, if my child brushes his teeth at least two times a day, can prevent tooth decay.", perceived barriers for oral health such as flossing and

brushing teeth with the example of the question "In my opinion, bleeding from gums causes that my child escapes from brushing.", perceived self-efficacy for oral-dental health such as flossing and brushing with the example question "I am sure my child can properly floss his/her teeth" [25].

Hiratsuka, in his study, used The Oral Health Belief Questionnaire instrument that measured the dimensions of the Health Belief Model (HBM), including perceived seriousness, the benefit of preventive practices, benefits of plaque control, the efficacy of dentists, and perceived importance [26]. While in the study conducted by Moghadam and colleagues involved eight items from HBM, including knowledge, 
perceived susceptibility, perceived severity, perceived benefits, perceived barriers, self-efficacy, cues to action, and preventive behavior [27].

In two different years, Wilson carried out research that focused on children's dental health using the HBM approach. In 2016, Wilson and colleagues used sixteen items to measure four key constructs of the Health Belief Model (HBM). These fundamental constructions include perceived vulnerability (carers' perception that their children are prone to cavities), seriousness (the degree to which caregivers believe oral health problems are serious), benefits, and barriers to engaging in recommended oral health behaviors [29]. Whereas his 2018 study used the Extended HBM (EHBM), sixteen items measured four primary constructs of the main Health Belief Model (HBM): perceived vulnerability, perceived severity, perceived benefit, and perceived inhibition [28].

\section{The Theory of Planned Behavior Framework in Efforts to Change Children's Oral Health}

A total of five studies included in this literature review used the Theory of Planned Behavior (TPB) approach to looking at the behavior of maintaining oral health by parents and children themselves. Based on the TPB concept, that intentions determine a person's behavior. This intention is reinforced by the individual's attitude towards behavior, subjective norms, and perceived behavioral control.

In their study on the determination of oral health behavior in children, Soltani and colleagues used Theory of Planned Behavior based questions that discussed maternal attitudes, subjective norms, perceived behavioral control, and intentions towards children's dental and oral health behavior [22]. Meanwhile, Adiatman and his team developed a TPB-based questionnaire focusing on children's oral and dental hygiene habits [23]. Clarke and Ridley used the Theory of Planned Behavior (TPB) to analyze attitudes, beliefs, parenting efficacy, and intention items related to caries prevention behavior. Theory of Planned Behavior (TPB) asserts a relationship between individual views, attitudes, intentions, perceived control over behavior, and actual possession. Some of the questions use the Theory of Planned Behavior (TPB) approach. Those questions samples include "I don't know how to brush my child's teeth properly," "if we brush our child's teeth twice a day, we can prevent our child getting tooth decay in the future," "I can control my child getting tooth decay," and "preventing tooth decay is the dentist responsibility" [24].

Elyasi and his team adopted Theory of Planned Behavior (TPB) to prepare their research instrument, which aims to examine parental attitudes, subjective norms, Perceived Behavioral Control (PBC), and intentions towards the presence of preschool children in dental examinations [30]. The intervention study conducted by Makvandi and colleagues used a questionnaire focusing on TPB-based questions covering attitudes, perceived behavioral control, intentions, knowledge, children's teeth cleaning, and demographic questions. Theory of Planned Behavior (TPB) of cognition (i.e., attitudes, perceived behavioral control, and) intentions) was measured indirectly (i.e., belief-based) [31].

\section{DISCUSSION}

This systematic study focuses on developing a framework for behavioral change to maintain oral health in preschool children through an in-depth review of published and peer-reviewed literature. The theme of the literature is the implementation of the Health Belief Model approach and the Theory of Planned Behavior. Overall, the articles included in this study and have met the inclusion criteria are ten articles from several countries globally.

There are five articles in each of the approaches used for the Health Belief Model (HBM) and Theory Planned Behavior (TPB). Overall, the instrument's preparation utilizing this model in the ten articles included is identical. In the Health Belief Model (HBM), all articles compose questions based on the guidelines for HBM, even though the questions or statements that are compiled or developed are not the same in format. Still, the dimensions of the items displayed represent the primary form of the HBM. The questions or statements compiled in each article generally include awareness of the dental and oral health status of children, perceptions of vulnerability to the possibility of suffering from dental and oral diseases, perceived severity of worsening dental and oral health problems, perceived benefits for dental and oral health by brushing and flossing, perceived barriers to oral-dental health such as flossing and brushing 
teeth, perceived self-efficacy for oral-dental health such as flossing and brushing teeth [25]. These questions or statements are briefly included in the HBM dimension, as other researchers implement the same approach (HBM). These dimensions know perceived susceptibility, perceived severity, perceived benefits, perceived barriers, self-efficacy, cues to action, and preventive behavior [27].

The HBM is one of the essential models that shows the relationship between health beliefs and behavior and is based on the assumption that preventive action is a person's belief in health [32]. Health Belief Model (HBM) is used for various health problems, including cervical cancer, osteoporosis, diabetes treatment, dental health, dental plaque control. This model focuses on motivation, past experiences, and a general focus on fluctuations in beliefs and can describe long-term and short-term health behaviors [33],[34].

The study that uses the Theory of Planned Behavior approach, as a whole, compiles question or statement items that focus on attitudes towards prevention, change control, external control, desire to brush children's teeth, desire to control children's sugar consumption, parental efficacy to touch children's teeth [24]. TPB is used to analyze attitudes, beliefs, parental effectiveness, and desired items related to caries prevention behavior. The TPB theory states that there is a relationship between individual views, attitudes, intentions, perceived control over behavior, and actual control over behavior. The theory assumes that people are involved in rational and cognitive-based decision-making processes. In this Clarke \& Ridley study, control beliefs (external control and opportunity control), normative beliefs (perceptions of the seriousness of decay), attitudes towards behavior (prevention attitudes), intentions (importance and intention to brush children's teeth and interests and preferences to control snack sugar).

Based on the results of the study of the relevant literature, it can be described a framework that represents the pattern of implementation or implementation of the HBM and TPB approaches as follows:

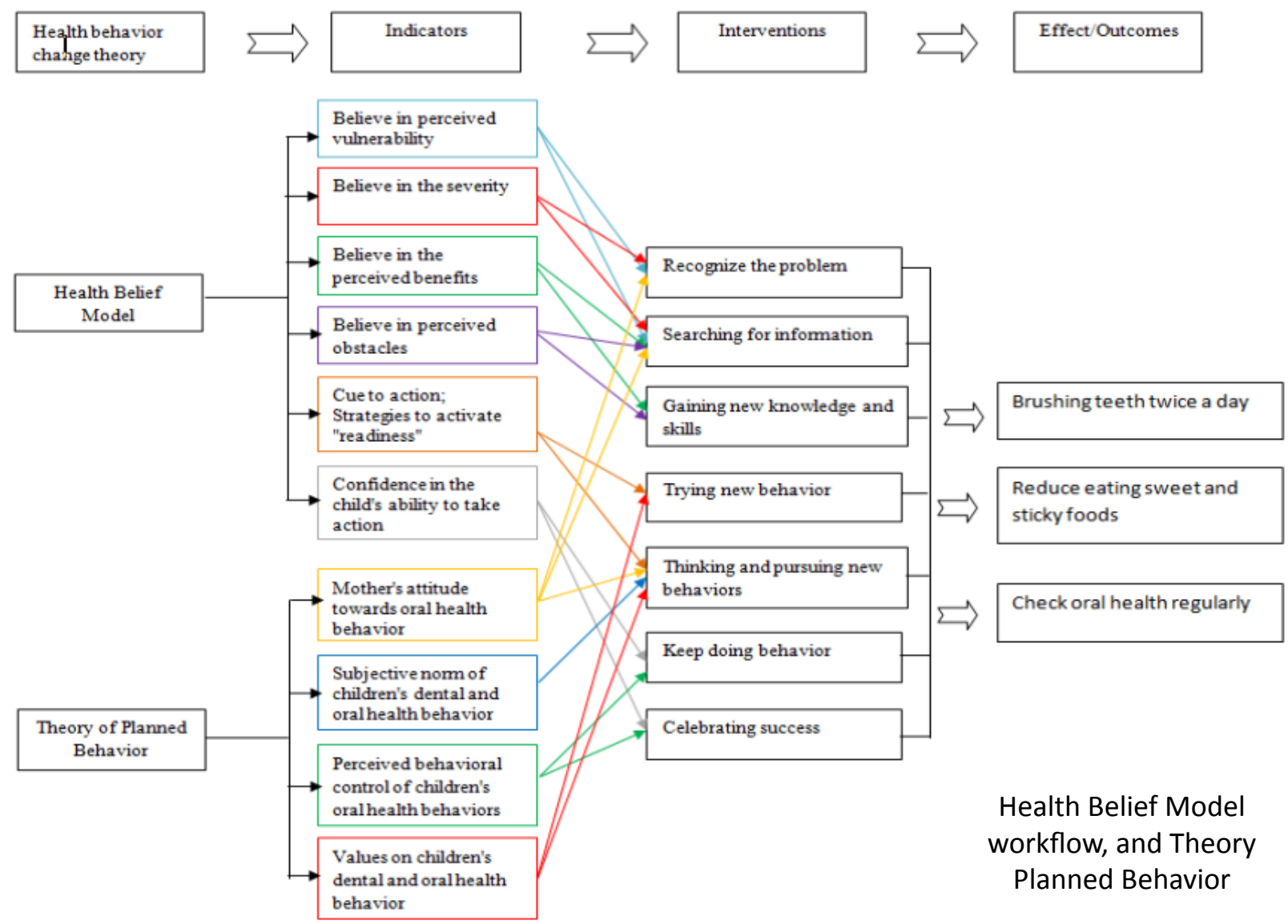


Some of the limitations mentioned include the accessibility of relevant articles in the database, which the author cannot do, besides the use of language, which the author limits to articles in English or Indonesian only. The number of pieces included in this study did not meet the requirements for a meta-analysis.

\section{CONCLUSION}

Both the Health Belief Model and the Theory of Planned Behavior can help improve behavior change in preschool children in maintaining oral health. Through HBM, parents can find support to set the best example for their children performing oral health care. Also, using the Theory of Planned Behavior approach increases parents' attitudes and beliefs, including intentions, about children's oral health and can ultimately improve oral health behavior.

\section{REFERENCES}

1. Mota A, Oswal KC, Sajnani DA, Sajnani AK. Oral health knowledge, attitude, and approaches of pre-primary and primary school teachers in Mumbai, India. Scientifica. 2016;2016.

2. Riedy CA, Weinstein P, Milgrom P, Bruss M. An ethnographic study for understanding children's oral health in a multicultural community. International Dental Journal. 2001;51(4):305-12.

3. Emilia O, Prabandari YS. Promosi kesehatan dalam lingkup kesehatan reproduksi. UGM PRESS; 2019.

4. Hasnidar H, Tasnim T, Sitorus S, Hidayati W, Mustar M, Fhirawati F, et al. Ilmu Kesehatan Masyarakat. Yayasan Kita Menulis; 2020.

5. Begzati A, Bytyci A, Meqa K, Latifi-Xhemajli B, Berisha M. Mothers' behaviours and knowledge related to caries experience of their children. Oral Health Prev Dent. 2014;12(2):133-40.

6. Kamolmatyakul S. Oral Health Knowledge, Attitude and Practices of Parents/Caregivers. Chapter. 2012;21:341-56.

7. Al-Darwish MS. Oral health knowledge, behaviour and practices among school children in Qatar. Dental research journal. 2016;13(4):342.

8. Touger-Decker R, Van Loveren C. Sugars and dental caries. The American journal of clinical nutrition. 2003;78(4):881S-892S.

9. Borges HC, Garbín CAS, Saliba O, Saliba NA, Moimaz SAS. Socio-behavioral factors influence prevalence and severity of dental caries in children with primary dentition. Brazilian oral research. 2012;26:564-70.

10. Baghaie H, Kisely S, Forbes M, Sawyer E, Siskind DJ. A systematic review and meta-analysis of the association between poor oral health and substance abuse. Addiction. 2017;112(5):765-79.
11. Allen PF. Assessment of oral health related quality of life. Health and quality of life outcomes. 2003;1(1):1-8.

12. Ramsay SE, Whincup PH, Watt RG, Tsakos G, Papacosta AO, Lennon LT, et al. Burden of poor oral health in older age: findings from a population-based study of older British men. BMJ open. 2015;5(12):e009476.

13. Watt RG, Petersen PE. Periodontal health through public health-the case for oral health promotion. Periodontology 2000. 2012;60(1):147-55.

14. Kandelman D, Arpin S, Baez RJ, Baehni PC, Petersen PE. Oral health care systems in developing and developed countries. Periodontology 2000. 2012;60(1):98-109.

15. Watt RG. Strategies and approaches in oral disease prevention and health promotion. Bulletin of the World Health Organization. 2005;83:711-8.

16. Petersen PE. The World Oral Health Report 2003: continuous improvement of oral health in the 21 st century-the approach of the WHO Global Oral Health Programme. Community Dentistry and oral epidemiology. 2003;31:3-24.

17. Petersen PE, Yamamoto T. Improving the oral health of older people: the approach of the WHO Global Oral Health Programme. Community dentistry and oral epidemiology. 2005;33(2):81-92.

18. Petersen PE. World Health Organization global policy for improvement of oral health-World Health Assembly 2007. International dental journal. 2008;58(3):115-21.

19. Cahyaningrum AN. Hubungan perilaku ibu terhadap kejadian karies gigi pada balita di paud putra sentosa. J Berk Epidemiol. 2017;5:142-51.

20. Pintauli S. Analisis hubungan perilaku pemeliharaan kesehatan gigi dan mulut terhadap status kesehatan gigi dan mulut siswa SD dan SMP di Medan. Jurnal Pendidikan dan Kebudayaan. 2010;16(4):376-90.

21. Abadi NYWP, Suparno S. Perspektif Orang Tua pada Kesehatan Gigi Anak Usia Dini. Jurnal Obsesi: Jurnal Pendidikan Anak Usia Dini. 2019;3(1):161-9.

22. Soltani R, Sharifirad G, Mahaki B, Eslami AA. Determinants of oral health behavior among preschool children: Application of the theory of planned behavior. Journal of Dentistry. 2018;19(4):273.

23. Adiatman M, Zhafarina AR, Rahardjo A, Badruddin IA, Prabawanti C. The Correlation between Mothers' Behaviors of Maintaining Their Children's Oral Hygiene and Early Childhood Caries (Based on the Theory of Planned Behavior). Journal of International Dental and Medical Research. 2017;10:619-27.

24. Clarke R, Shaw-Ridley M. Parental attitudes and beliefs about preschooler preventive oral health behaviors: implications for health promotion. Journal of immigrant and minority health. 2019;21(4):731-6.

25. Gharlipour Z, Sharifirad G, Kazazloo Z, Khoshdani Farahani P, Mohebi S. Factors affecting oral-dental health in children in the viewpoints of mothers referred to the health centers in Qom city: using the health belief model. International Journal of Pediatrics. 2016;4(9):3449-60.

26. Hiratsuka VY, Robinson JM, Greenlee R, Refaat A. Oral health beliefs and oral hygiene behaviours among parents of urban Alaska Native children. International journal of circumpolar health. 2019;78(1):1586274. 
27. Hossein, B.M.M, Mahnoosh, M.A, Mina, B, Siamak S. Evaluation of oral hygiene care of under 4 years old children by their mothers based on the Health Belief Model. 2015;

28. Wilson AR, Brega AG, Thomas JF, Henderson WG, Lind KE, Braun PA, et al. Validity of measures assessing oral health beliefs of American Indian parents. Journal of racial and ethnic health disparities. 2018;5(6):1254-63.

29. Wilson AR, Brega AG, Campagna EJ, Braun PA, Henderson WG, Bryant LL, et al. Validation and impact of caregivers' oral health knowledge and behavior on children's oral health status. Pediatric dentistry. 2016;38(1):47-54.

30. Elyasi M, Lai H, Major PW, Baker SR, Amin M. Modeling the Theory of Planned Behaviour to predict adherence to preventive dental visits in preschool children. PloS one. 2020;15(1):e0227233.
31. Makvandi Z, Karimi-Shahanjarini A, Faradmal J, Bashirian S. Evaluation of an oral health intervention among mothers of young children: a clustered randomized trial. Journal of research in health sciences. 2015;15(2):88-93.

32. Solhi M, Shojaeizadeh M, Seraj B, Faghihzadeh S. Oral health education through health belief model. KOWSAR MEDICAL JOURNAL; 2000.

33. Xiang B, Wong HM, Perfecto AP, McGrath CPJ. Modelling health belief predictors of oral health and dental anxiety among adolescents based on the Health Belief Model: a cross-sectional study. BMC public health. 2020;20(1):1-12.

34. Setiawan AS, Zubaedah C. Application of health belief model on child's dental visit postponement during the covid-19 pandemic. European Journal of Dentistry. 2020;14(S 01):S7-13. 